PSYCHOLOGICAL PROBLEMS OF THE CHILD AND HIS FAMILY 


\section{Psychological Problems of}

EDITED BY

AND 
A TEXTBOOK OF BASIC CHILD AND ADOLESCENT

PSYCHIATRY FOR STUDENTS AND PRACTITIONERS OF

MEDICINE AND THE MENTAL HEALTH PROFESSIONS.

\title{
the Child and His Family
}

\author{
Paul D. Steinhauer \\ Quentin Rae-Grant
}

Macmillan Education 
() Macmillan of Canada 1977

Softcover reprint of the hardcover 1st edition 1977 978-0-333-24020-5

All rights reserved - no part of this book may be reproduced in any form without permission in writing from the publisher, except by a reviewer who wishes to quote brief passages in connection with a review written for inclusion in a magazine or newspaper.

First published in Canada in 1977 by The Macmillan Company of Canada Ltd

First published in the U.K. in 1978 by THE MACMILLAN PRESS LTD

London and Basingstoke

Associated companies in Delhi Dublin

Hong Kong Johannesburg Lagos Melbourne

New York Singapore and Tokyo

\section{British Library Cataloguing in Publication Data}

Psychological problems of the child and his

family

I. Child psychiatry

I. Steinhauer, Paul D II. Rae-Grant, Quentin

618.9'28'9 RJ499

ISBN 978-1-349-81466-4 ISBN 978-1-349-81464-0 (eBook)

DOI 10.1007/978-1-349-81464-0

This book is sold subject to the standard conditions of the Net Book Agreement 
The editors would like to dedicate this book to

DRS. E. JAMES ANTHONY, LEON EISENBERG, and the late HYMAN S. LIPPMAN

whose example and friendship have had such an influence

on their careers in academic child psychiatry,

and to their colleagues on the

Committee on Child and Adolescent Psychiatry,

Department of Psychiatry,

University of Toronto 


\section{Contents}

Contributing Authors $\mathrm{x}$

Preface xiii

UNIT ONE THE CHILD AND HIS FAMILY

1. Normal Child Development 2

BONNIE ROBSON, KLAUS MINDE

2. The Developmental Challenges of Adolescence 29 HARVEY GOLOMBEK, JAMES WILKES, ARTHUR P. FROESE

3. The Child and His Family 49 PAUL D. STEINHAUER

UNIT TWO ASSESSMENT OF THE CHILD AND HIS FAMILY

4. A Guide to the Assessment of The Child and His Family 72 ELSA BRODER

UNIT THREE COMMON SYNDROMES IN CHILD PSYCHIATRY

5. Childhood Developmental Problems 100 GORDON WARME

6. Psychoneurosis, Behaviour Disorders, and Personality Disorders in Children 126 PAUL D. STEINHAUER, GRAHAM BERMAN

7. Suicide and Depression in Children and Adolescents 151 BARRY GARFINKEL, HARVEY GOLOMBEK

8. Psychoses in Childhood and Adolescence 165 HARVEY R. ALDERTON 
viii CONTENTS

9. Psychophysiological Disorders in Childhood and Adolescence 191 ROBERT SIMMONS

10. Organic Brain Syndromes in Childhood and Adolescence 208 MILADA HAVELKOVA

11. The Child Whose Behaviour Is Antisocial 225 ELSA BRODER

12. The Child With a Learning Disorder 242 WILLIAM A. HAWKE, STANLEY R. LESSER

13. Psychiatric Aspects of Mental Retardation 265 WILLIAM A. HAWKE

14. Adolescents and the Drug Scene 284 SAUL LEVINE

\section{UNIT FOUR PSYCHOLOGICAL CRISES FOR CHILD AND FAMILY}

15. Psychological Crises in the Child and His Family 296 PAUL D. STEINHAUER, DAVID DICKMAN

16. Psychological Aspects of Chronic Illness 313 PAUL D. STEINHAUER, QUENTIN RAE-GRANT, DAVID N. MUSHIN

17. Hospitalization and Its Meaning to the Child and His Family 334 JAMES VAN LEEUWEN

18. The Dying Child and His Family 347 ED PAKES

19. The Battered Child and His Family 361 SIMON KREINDLER

20. Family Disruption and Its Effects 371 GRAHAM BERMAN

21. The Child's Reactions to Dental Care 383 SOL GOLDSTEIN

UNIT FIVE PRINCIPLES OF INTERVENTION

22. General Principles of Treatment in Child Psychiatry 394 DAVID N. MUSHIN 
Contents ix

23. The Role of Drugs in the Treatment of Disturbed Children 413 KLAUS MINDE

24. The Primary Care and Referral of Children with Emotional and Behavioural Disorders 427

QUENTIN RAE-GRANT

Clossary 439

Index 450 


\section{Contributing Authors}

\section{Dr. Harvey R. Alderton}

Associate Professor, Department of Psychiatry, University of Toronto.

Formerly, Director of Training and Research, Thistletown Regional Centre.

\section{Dr. Graham Berman}

Assistant Professor, Department of Psychiatry, University of Toronto. Staff Psychiatrist, Hospital for Sick Children.

\section{Dr. Elsa Broder}

Assistant Professor, Department of Psychiatry, University of Toronto. Staff Psychiatrist, C. M. Hincks Treatment Centre.

\section{Dr. David Dickman}

Assistant Professor, Department of Psychiatry, University of Toronto. Staff Psychiatrist, Hospital for Sick Children.

\section{Dr. Arthur P. Froese}

Assistant Professor, Department of Psychiatry, University of Toronto. Staff Psychiatrist, Hospital for Sick Children.

\section{Dr. Barry Garfinkel}

Lecturer, Department of Psychiatry, University of Toronto.

Staff Psychiatrist, C. M. Hincks Treatment Centre.

\section{Dr. Sol Goldstein}

Assistant Professor, Department of Psychiatry, University of Toronto. Staff Psychiatrist, Hospital for Sick Children. 


\section{Dr. Harvey Golombek}

Assistant Professor, Department of Psychiatry, University of Toronto.

Staff Psychiatrist, C.M. Hincks Treatment Centre.

\section{Dr. Milada Havelkova}

Assistant Professor, Department of Psychiatry, University of Toronto.

Staff Psychiatrist, Hospital for Sick Children.

\section{Dr. William A. Hawke}

Special Lecturer, Department of Psychiatry, University of Toronto.

Emeritus of Pediatrics, University of Toronto,

Honorary Consultant, Hospital for Sick Children.

\section{Dr. Simon Kreindler}

Lecturer, Department of Psychiatry, University of Toronto.

Staff Psychiatrist, Hospital for Sick Children.

\section{Dr. Stanley R. Lesser}

Associate Professor, Department of Psychiatry, University of Toronto. Associate Psychoanalyst, Columbia University.

Senior Staff Psychiatrist, Hospital for Sick Children.

\section{Dr. Saul Levine}

Associate Professor, Departments of Psychiatry and Psychology,

University of Toronto.

Senior Staff Psychiatrist, Hospital for Sick Children.

\section{Dr. Klaus Minde}

Associate Professor and Director of Research in Child Psychiatry,

Department of Psychiatry, University of Toronto.

Senior Staff Psychiatrist, Hospital for Sick Children.

\section{Dr. David N. Mushin}

Honorary Assistant Child Psychiatrist, Prince Henry's Hospital, Melbourne, Australia.

\section{Dr. Ed Pakes}

Assistant Professor, Department of Psychiatry, University of Toronto.

Senior Staff Psychiatrist, Hospital for Sick Children.

\section{Dr. Quentin Rae-Grant}

Professor of Child Psychiatry, Department of Psychiatry, University of Toronto.

Psychiatrist-in-Chief, Hospital for Sick Children.

\section{Dr. Bonnie Robson}

Assistant Professor, Department of Psychiatry, University of Toronto.

Staff Psychiatrist, C. M. Hincks Treatment Centre. 


\section{Dr. Robert Simmons}

Assistant Professor, Department of Psychiatry, University of Toronto. Staff Psychiatrist, Hospital for Sick Children.

\section{Dr. Paul D. Steinhauer}

Associate Professor and Director of Training in Child Psychiatry, Department of Psychiatry, University of Toronto.

Senior Staff Psychiatrist, Hospital for Sick Children.

\section{Dr. James VanLeeuwen}

Assistant Professor, Department of Psychiatry, University of Toronto. Senior Staff Psychiatrist, Hospital for Sick Children.

\section{Dr. Gordon Warme}

Associate Professor, Department of Psychiatry, University of Toronto. Chief, Child and Adolescent Service, Clarke Institute of Psychiatry. Staff Psychiatrist, Hospital for Sick Children.

\section{Dr. James Wilkes}

Honorary Lecturer, Department of Psychiatry, University of Toronto.

Director, Child and Adolescent Psychiatry, Scarborough Centenary Hospital. 


\section{Preface}

Preparing an introductory text presents an intriguing series of challenges to the editors. The text must be basic enough to be readily comprehensible, while approaching its subject matter in an authoritative and comprehensive way. It must order and present a large number of facts and key concepts in a language and in a manner that are clear, organized, and sequential. Highly technical terms and concepts must be so presented that even the reader new to the area can relate them to his own experience or to concrete illustrations supplied by the text. If it is to succeed in its task, it is not enough that it be read and memorized; it must be understood and even enjoyed.

Psychological Problems of the Child and His Family is intended to present the basic principles of child and adolescent psychiatry while meeting the above criteria. It attempts to cover the broad subject area of child and adolescent psychiatry from biological, developmental, psychoanalytic, and systems perspectives. Even more important, it attempts to integrate these conceptual approaches so that readers from a variety of disciplines are guided towards a practical approach in understanding and dealing with patients and their families.

Throughout the text, the child is viewed as both an individual, with his own internal network of drives and defences, and as a member of a family and social system. An integration between these inner (intrapsychic) and outer (interpersonal and social) aspects of the child's reality is continually kept in focus. Consistent emphasis is placed on the 
process of development and on the effects of blocks and deviations in the development of the child's personality and functioning.

It is hoped that the concepts and topic areas of psychological disturbance in the child and his family are conveyed in a clear and well-organized manner. Determined efforts have been made to minimize the use of jargon. Students and practitioners of medicine and allied professions do not require familiarity with psychiatric terminology to understand and follow the text. Where technical terms are used, they are clearly defined. Key concepts are illustrated by schematic diagrams and brief clinical vignettes. A glossary of medical and technical terms is included, and key references are annotated to help the interested reader pursue in greater depth areas of his own inclination.

The editors would like to express their appreciation to their colleagues on the Committee on Child and Adolescent Psychiatry, Department of Psychiatry, University of Toronto, who have made available at all times their knowledge, their experience, and their friendship. In addition, we would like to thank the following, without whose assistance the text could not have been prepared: Mr. Allan Kaplan, for his help in the preparation of the bibliography and in indexing; Mr. John Fanning, for his assistance in the preparation of the glossary; Mr. David Steinhauer, for proofreading and editorial assistance; the secretarial staff of the Department of Psychiatry, Hospital for Sick Children, with special thanks to Miss Barbara Wood for the typing and preparation of the manuscript.

The guidance and encouragement of Mr. Rolf Lockwood and Mr. Virgil Duff of Macmillan of Canada with regard to technical aspects of preparing the manuscript has been much appreciated.

$$
\text { P.D.S. and Q.R.-G. }
$$

